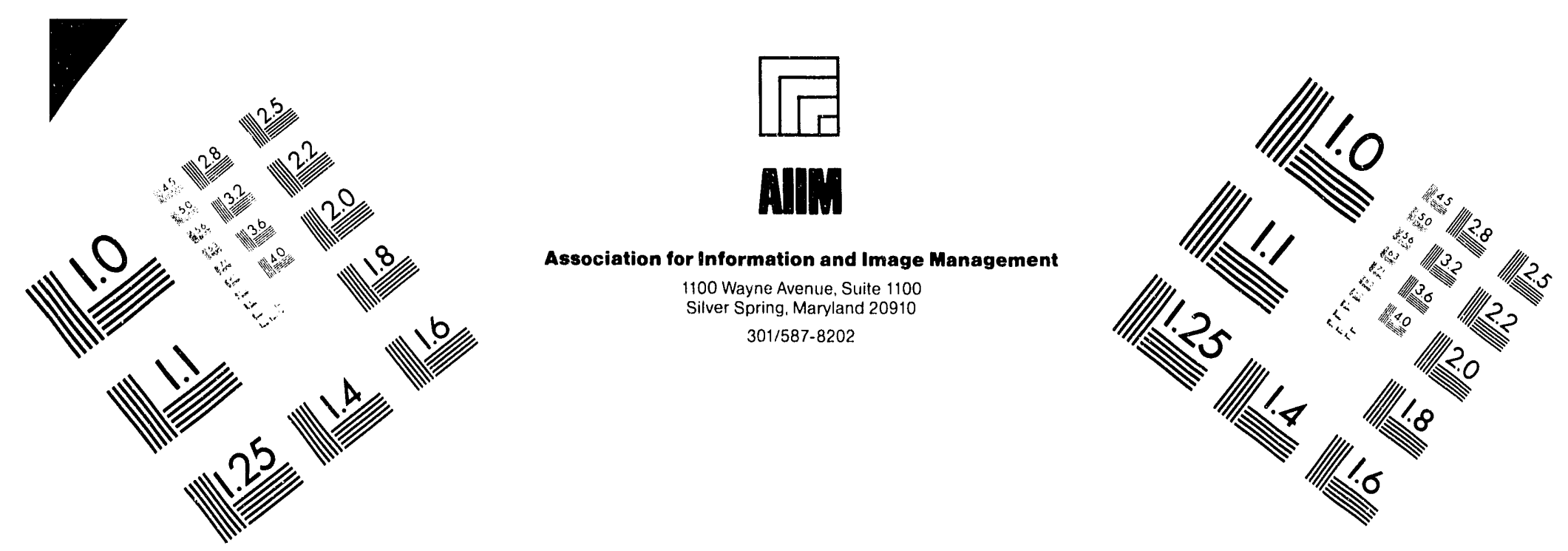

\title{
Centimeter
}

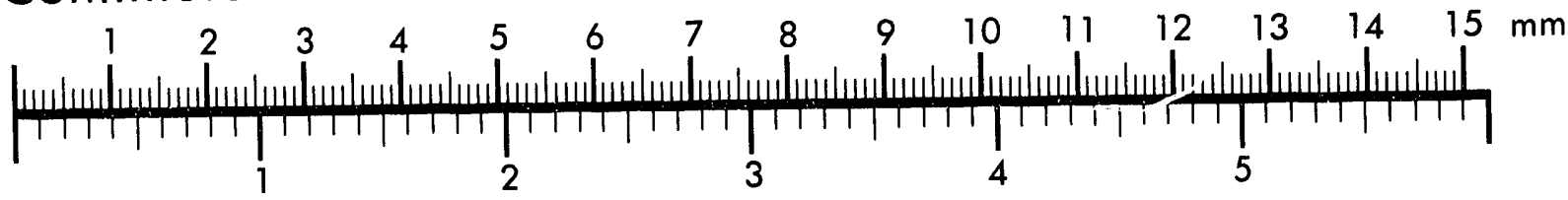
Inches
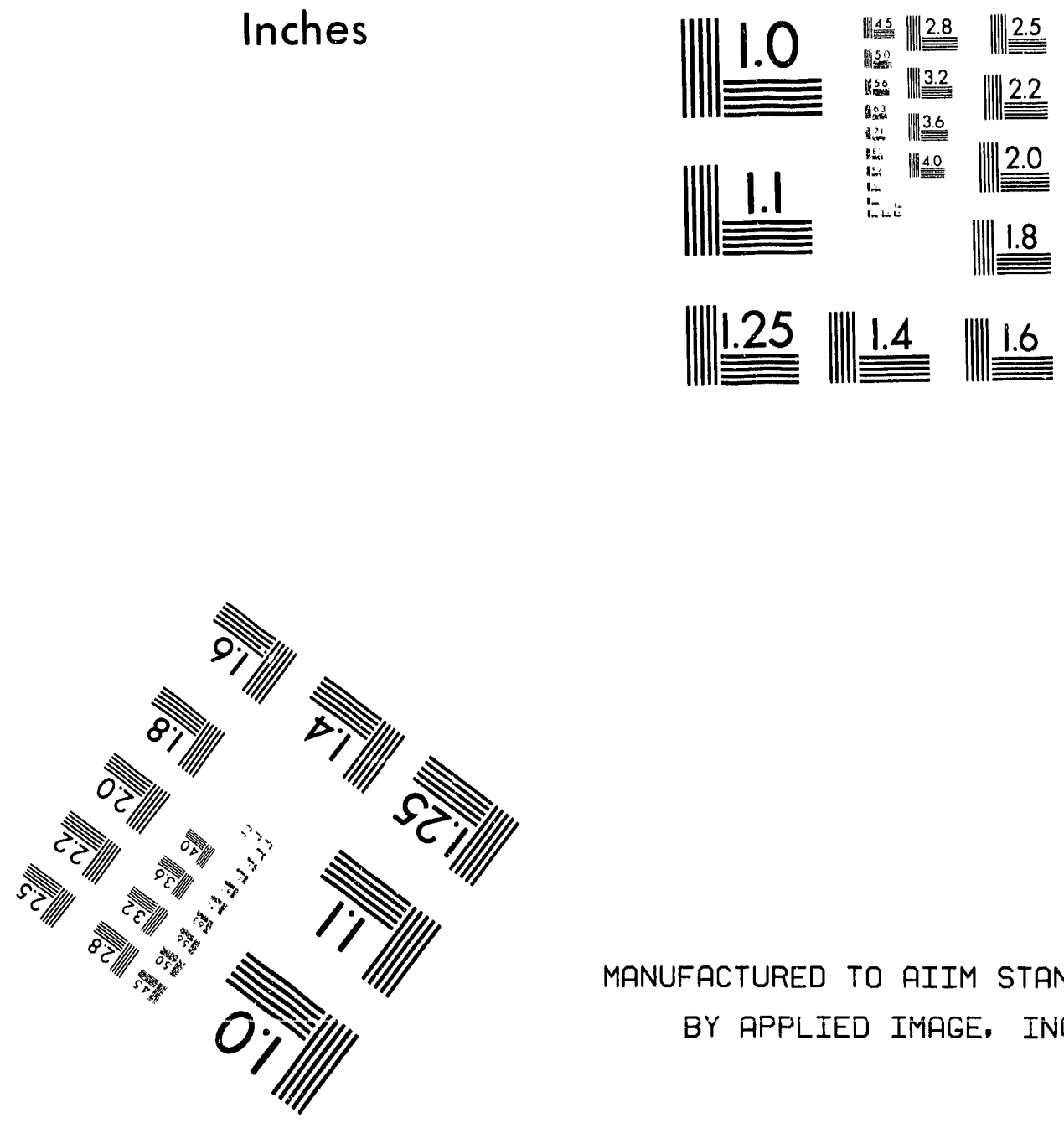

MANUFACTURED TO AIIM STANDARDS

BY APPLIED IMAGE, INC.

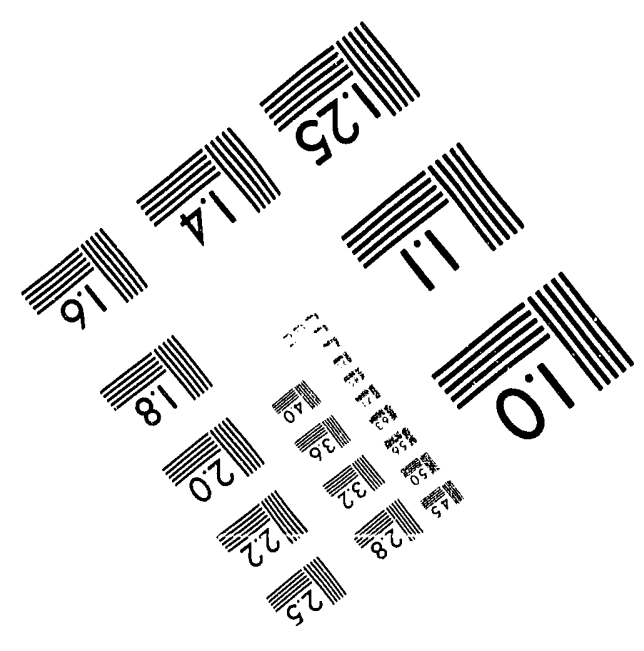



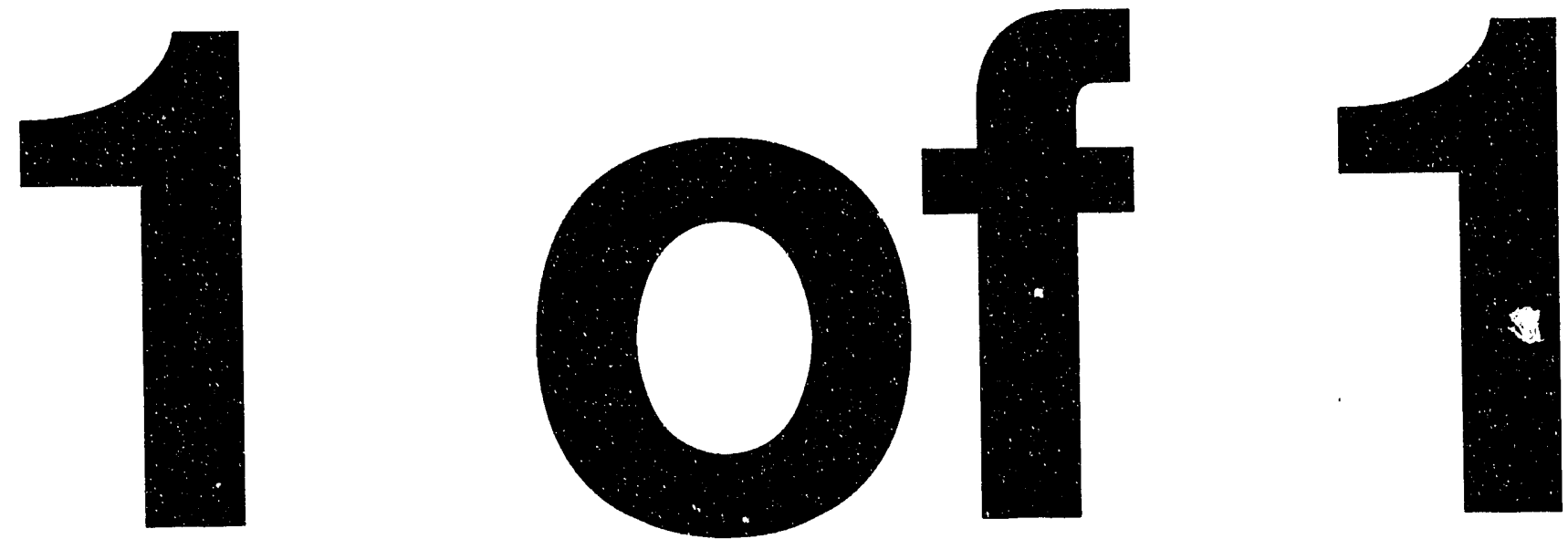


\section{AMMONIUM GENERATION DURING SRAT CYCLE (U)}

by C.W. Hsu

Westinghouse Savannah River Company

Savannah River Site

Aiken, South Carolina 29808

Other Authors:

This paper was prepared in connection with work done under Contract No. DE-AC09-89SR18035 with the U. S. Department of Energy. By acceptance of this paper, the publisher and/or recipient acknowledges the U. S. Government's right to retain a nonexclusive, royalty-free license in and to any copyright covering this paper, along with the right to reproduce and to authorize others to reproduce all or part of the copyrighted paper.

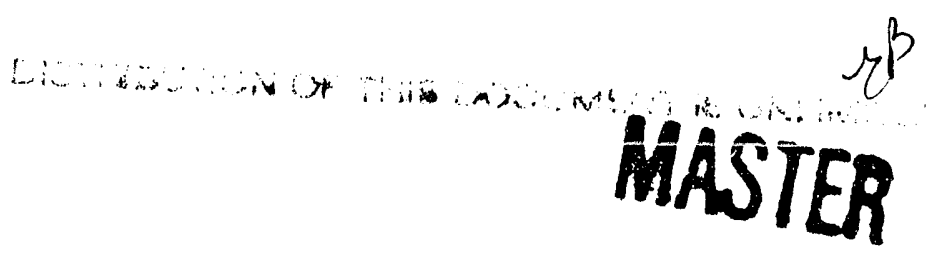




\section{DISCLAIMER}

This report was prepared as an account of work sponsored by an agency of the United States Government. Neither the United Sta:es Government nor any agency thereof, nor any of their employees, makes any warranty, express or implied, or assumes any legal liability or responsibility for the accuracy, completeness, or usefulness of any information, apparatus, product, or process disclosed, or represents that its use would not infringe privately owned rights. Reference herein to any specific commercial product, process, or service by trade name, trademark, manufacturer, or otherwise does not necessarily constitute or imply its endorsement, recommendation, or favoring by the United States Government or any agency thereor. The views and opinions of authors expressed herein do not necessarily state or reflect those of the United States Government or any agency thereof.

This report has been reproduced directly from the best available copy.

Available to DOE and DOE contractors from the Office of Scientific and Technical Information, P.O. Box 62, Oak Kidge, TN 37831; prices available from (615) 576-8401, FTS 626-8401.

Available to the public from the National Technical Information Service, U.S. Department of Commerce, 5285 Port Royal Rd., Springfield, VA 22161. 


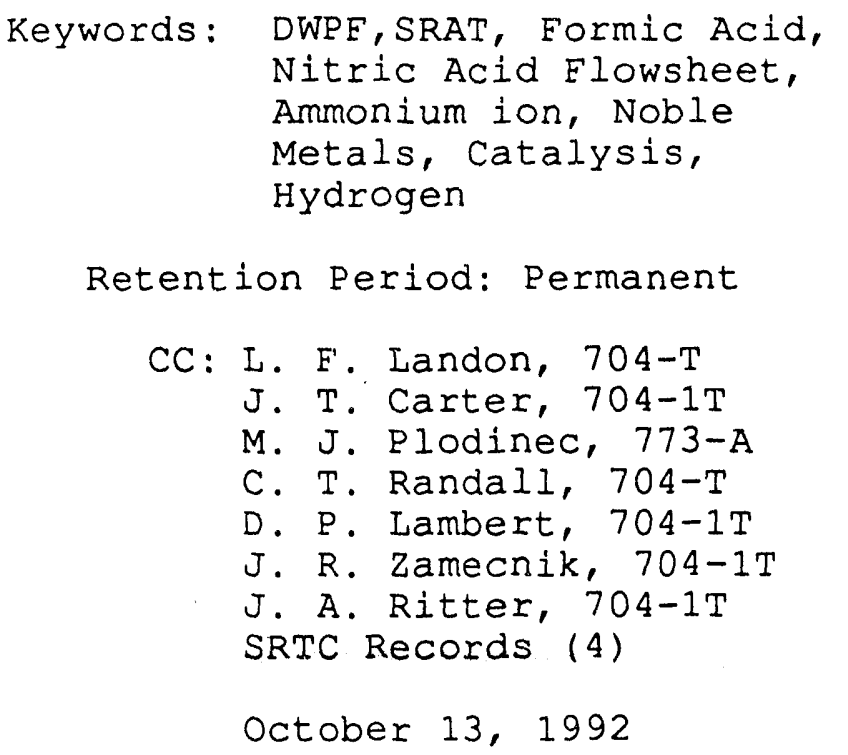

TO: E. W. HOLTZSCHEITER, 773-A

EROM : C. W. HSU, 704-1T

\section{AMMONIUM GENERATION DURING SRAT CYCIE(U)}

\section{SUMMARY}

During the bench-scale experiments of studying the hydrogen generation during the sludge treatmient cycle, ammonium ion production was also monitored. It was found that:

- During a simulation of the DWPF Cold Chemical Runs SRAT cycle no detectable amount of ammonium ions was generated when treating a non-noble-metal containing sludge simulant according to the nitric acid flowsheet.

- Ammonium ions were generated during the SRAT-SME cycle when treating the noble-metal containing sludge with either formic acid or nitric acid/late-washing PHA. This is due to the reaction between formic acid and nitrate catalyzed by the noble metals in the sludge simulant. Ammonium ion production closely followed the hydrogen evolution from the catalytic decomposition of formic acid.

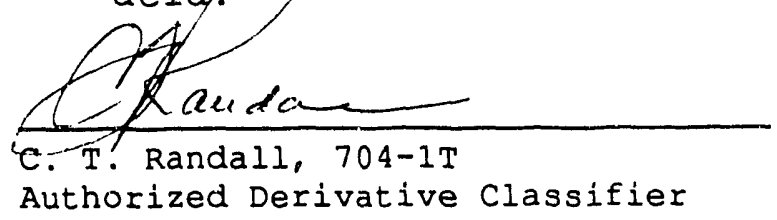




\section{INTRODUCTION}

During the IDMS noble-metal demonstration runs ammonium nitrate deposition was found in the vessel vent system of feed preparation area. ${ }^{1}$ The reference flowsheet at the time was to use formic acid to treat the sludge in the DWPF Chemical processing Cell (CPC) and to use hydroxylammonium nitrate (HAN) to destroy the nitrite in the tetraphenylborate precipitate slurry in the salt Processing Cell (SPC). The primary source of the ammonia in the CPC vent system was attributed to the ammonium nitrate in the incoming precipitate hydrolysis aqueous product (PHA). Ammonium nitrate is the product of decomposition of excess HAN. A secondary source was the ammonium ion generated in the SRAT and SME during formic acid treatment of sludge simulant containing noble metals.2,3

A late washing flowsheet ${ }^{4}$ was subsequently recommended to reduce the nitrite in the precipitate slurry to less than $0.01 \mathrm{M}$ prior to hydrolysis, and a nitric acid flowsheet was proposed to substitute part of the formic acid to treat the sludge in the SRAT. 5

In one series of scoping experiments at the new flowsheet simulation, for determining the hydrogen generation rate using a sludge simulant, ammonia generation in the sludge was monitored by analyzing the concentration of ammonium ions in the sludge, condensate, scrub solution for the offgas and the aqueous rinse from the glass condenser. This report summarizes the results of the production of ammonia during the SRAT cycle.

\section{RESUITS AND DISCUSSION}

From the results of these experiments it appears that the generation of ammonia is affected by several factors: the presence of active noble metals that catalyze the formic acid decomposition reaction; the presence of formic acid and nitrate; and the length of time that the sludge was boiling once the catalysts are activated to produce hydrogen. Some of the observations will be described below.

\section{Ammonium Generation During Treatment of Sludge with Formic} Acid

Figure 1 shows the profiles of ammonium ion concentration in the sludge during acidification of a noble-metal containing Purex sludge simulant $(0.07 \mathrm{M}$ nitrite) with formic acid. The noble metal loadings were 0.0437 wt: $\mathrm{Rh}, 0.093 \mathrm{wt} \% \mathrm{Pd}$ and 0.216 wt: Ru, based on the sludge solids. Formic acid was added at $93^{\circ} \mathrm{C}$ over three hours and then the sludge was refluxed at boiling for six hours. Ammonium ions were 
detected only in the reflux period after the catalysts are activated and a substantial amount of hydrogen evolved. Apparently, the noble metals that catalyze the hydrogen evolution also catalyze the reduction of nitrate with formic acid/formate to produce ammonium ion. No ammonium ion was detected in the acidic scrub of a vapor exiting the condenser. This particular experiment did not include the PHA evaporation cycle. Therefore the cycle time was considerably shorter than the other experiments for the nitric acid flowsheet.

Ammonium Generation During Treatment of Sludge with Nitric Acid and Late-Wash PHA

A nitric acid flowsheet 5 was recommended recently to substitute part of the formic acid and utilize the excess formic acid already present in the incoming PHA to treat the sludge. A Purex sludge simulant $(0.06 \mathrm{M}$ nitrite, 12.6 wto solid) was treated with a predetermined amount of nitric acid followed by PHA addition and evaporation. Afterwards, the treated sludge was refluxed for an extended period to ensure a definite decline of hydrogen evolution. The results of ammonium ion generation from these experiments are described below.

a. Sludge Simulant without Noble Metals (Cold Chemical Run)

In one experiment the noble metals were intentionally left out of the purex sludge to simulate a Cold Chemical Run. Nitric acid was added to treat a Purex sludge followed by PHA evaporation. Throughout the SRAT cycle and an additional ten-hour reflux period, ammonium ion was not detected in the sludge, condensate, scrub solution and the condenser rinse liquid.

b. Sludge Simulant Containing Noble Metals

Several runs were made using the nitric acid flowsheet and PHA prepared from late-wash hydrolysis to treat a Purex sludge containing the full complement of noble metals. Again, ammonium ion was not detected before the hydrogen evolution started. Similar to the experiment where formic acid was used to treat the sludge, ammonium ion generation usually followed the hydrogen evolution. Two examples are shown in Figures 2 and 3 . Depending on the $\mathrm{pH}$ of the sludge, ammonium ions can be present in the sludge, the condensate, acid scrub of the vapor exiting the condenser, or in he liquid adhering to the inside of the condenser. It is worth noting that because $\mathrm{CO}_{2}$ was generated when formic acid decomposition was occurring, the predominant species of the ammonium ions in the condenser was determined to be ammonium carbonate. The fact that the bulk of ammonia was usually 
generated only after hydrogen peaked indicated the catalysts that accelerated the decomposition of formic acid to generate hydrogen could also be responsible for the production of ammonium ions. Table I shows the amount of ammonilum ions produced in several bench-scale runs using the nitric acid flowsheet.

c. PHA from Irradiated and Washed Precipitate Feed

In one experiment (Run \#22) PHA from hydrolysis of an irradiated and washed precipitate slurry was used. Small. amount of ammonium ion, 8 to $69 \mathrm{mg} / \mathrm{L}$, was detected in the condensate during PHA evaporation before hydrogen evolution. This is because the there is small amount of ammonium ion, less than $76 \mathrm{mg} / \mathrm{L}$, in the incoming PHA. More ammonia was present in the sludge later on in the cycle. Still, the total quantity is less than Run \#19 when a PHA from an unirradiated precipitate was used (See Table 1) This agrees well with the hydroyen generation data. As less hydrogen was generated with this particular PHA compared with the corresponding run where PHA from an unirradiated precipitate slurry was used, less total amount of ammonium was also generated.

\section{CONCIUSION}

In the absence of noble metals in the sludge, no detectable ammonium ions are generated in the SRAT cycle.

Ammonium ions are generated in the SRAT-SME cycle when treating the noble-metal containing sludge simulant with either formic acid or nitric acid/late-washing PHA. This is due to the reaction between formic acid and nitrate catalyzed by noble metals. Ammonium ion generation seems to be closely related to the hydrogen generation caused by catalytic decomposition of formic acid. The conditions that increase or decrease the hydrogen generation also correspondingly influence the amount of ammonium ions generated in the melter feed preparation cycle. Production of ammonium ions in the DWPF needs to be expected when processing the radioactive sludges that would generate hydrogen.

\section{REFERENCES}

1. J. T. Carter, D. H. Miller, R. E. Eibling, L.M. Lee, L. F. Landon, and J. C. Marek, "Recommendations for Control of Ammonium Nitrate Deposits in the DWPF Process Vessel Vent System", WSRC-RP-91-1174 (1992).

2. J.C. Marek, "Defense Waste Processing Facility: Report of Task Force on Options to Mitigate the Effect of Nitrite on DWPF Operations (U)", USDOE Report WSRC-TR-92-67, Savannah River Site, Aiken, SC 29808 (1992). 
3. C. W. Hsu and J. A. Ritter, "Study on Hydrogen Evolution During Treatment of SRS High-Level Radioactive Sludge with Formic ACid", USDOE Report WSRC-MS-92-270, Savannah River Site, Aiken, SC 29808 (1992).

4. E. W. Holtzscheiter, "Resolution of Late Wash Technology Issues", WSRC-PR-1092TL, September 18, 1992.

5. E. W. Holtzscheiter, "Nitric Acid Flowsheet - Defense Waste Processing Facility (U) ", WSRC-RP-92-1003TL, August 20, 1992 . 


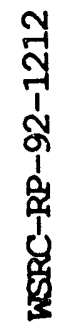

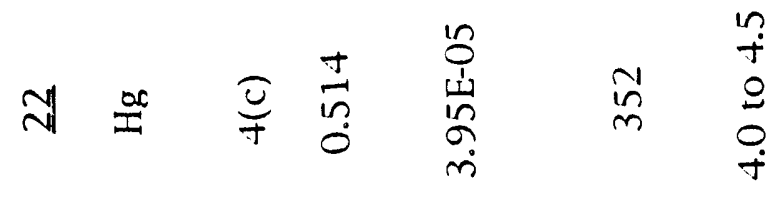

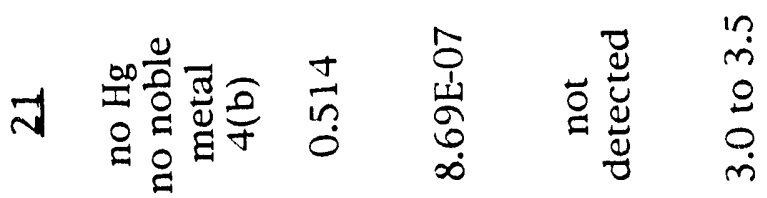

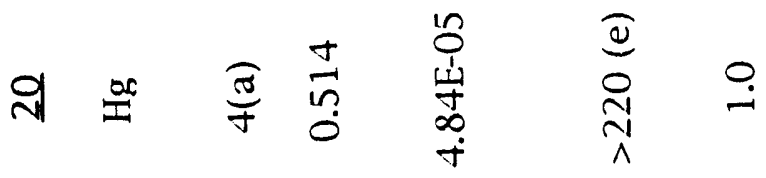

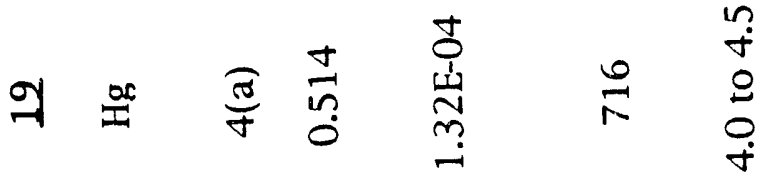

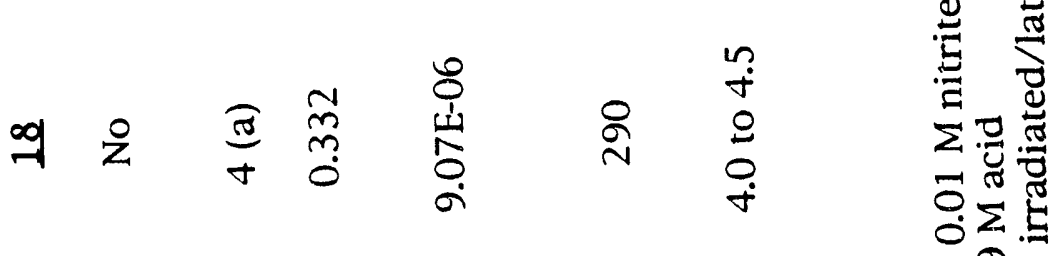

8

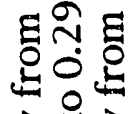

귱류

苋茓 苋

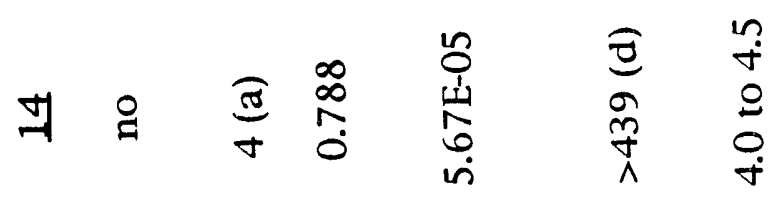

它尔

ष定宇

ฮ.

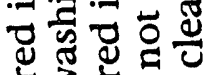

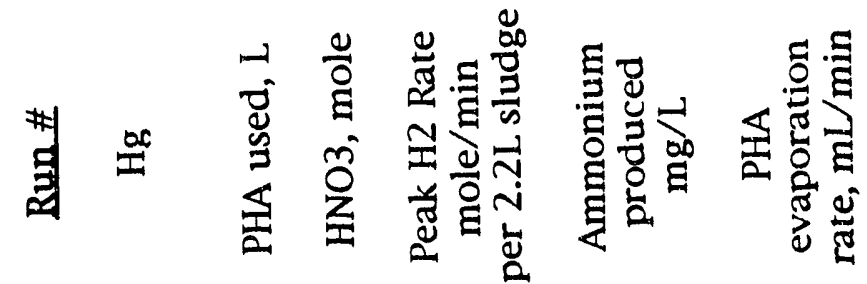

뉸도

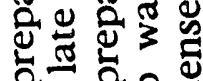

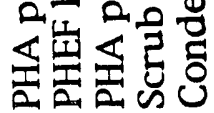

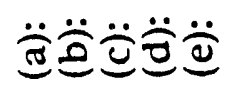




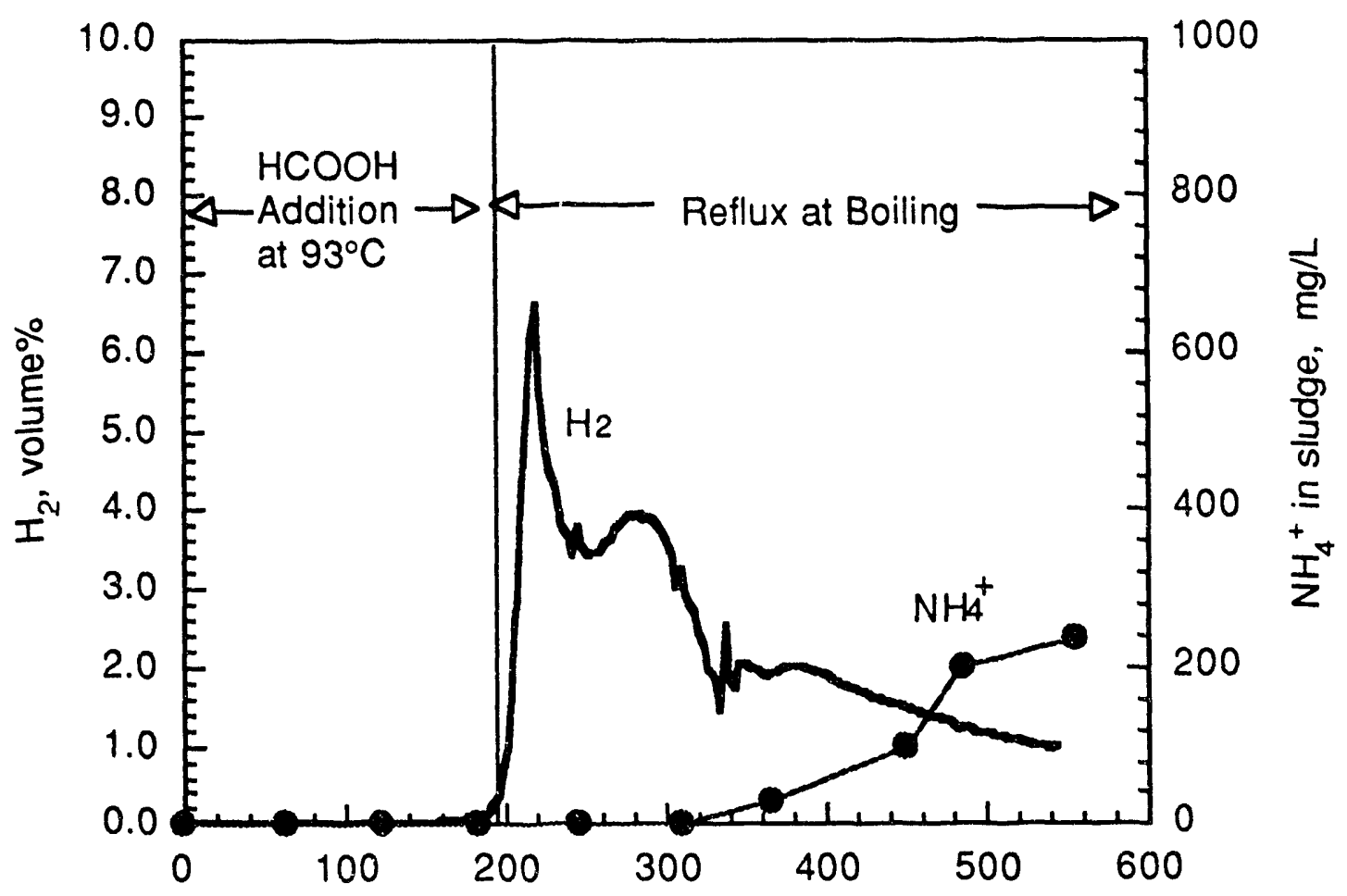

Eigure 1. Hydrogen and ammonium profiles during treatment of sludge simulant containing noble metals with formic acid. $(60 \mathrm{~mL} 90$ wt: formic acid per liter of 15 wt: Purex sludge) 

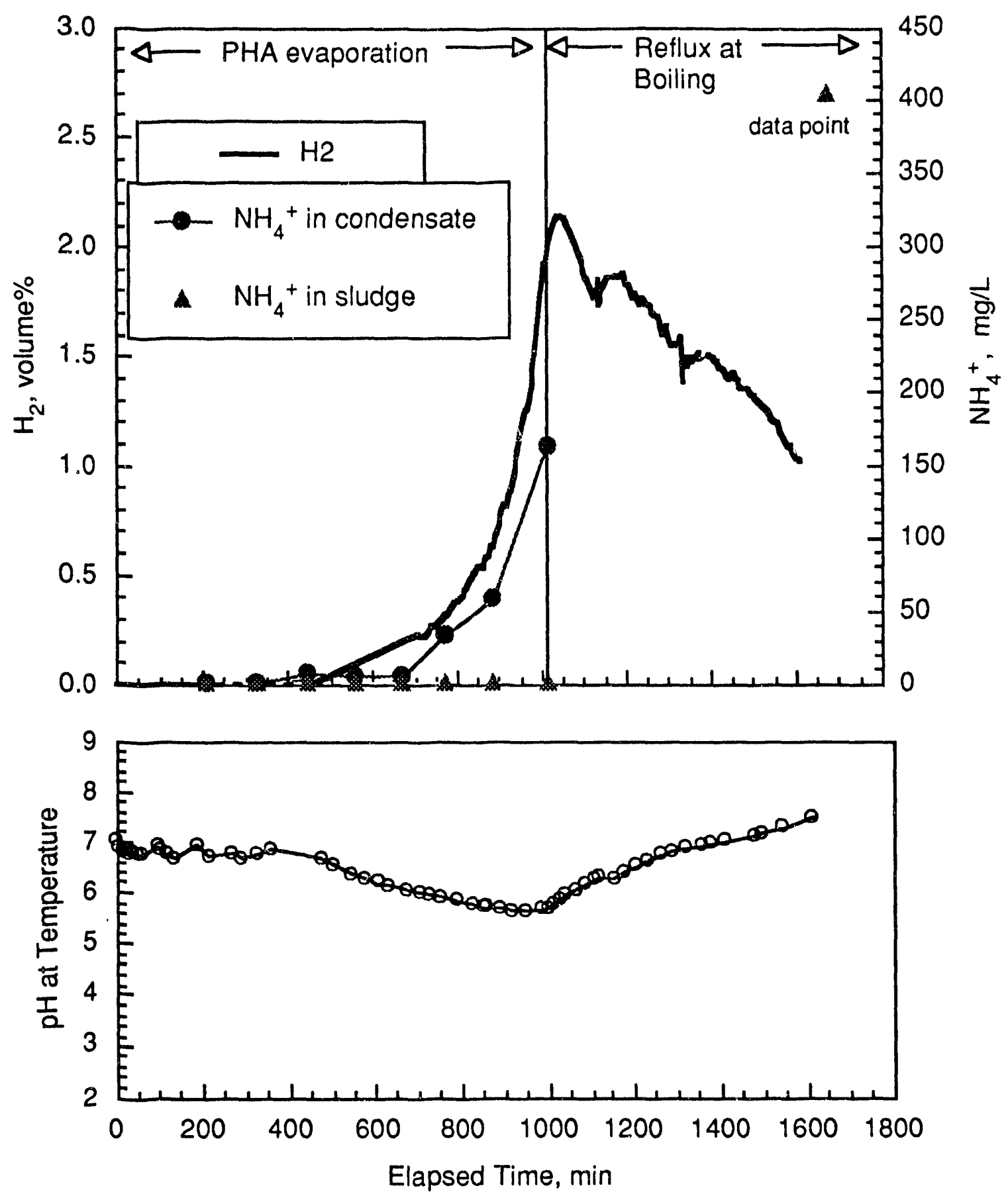

Figure 2. Time-dependence of sludge pH at boiling, ammonium ions in the sludge, condensate and hydrogen profile during Runt \#19. 


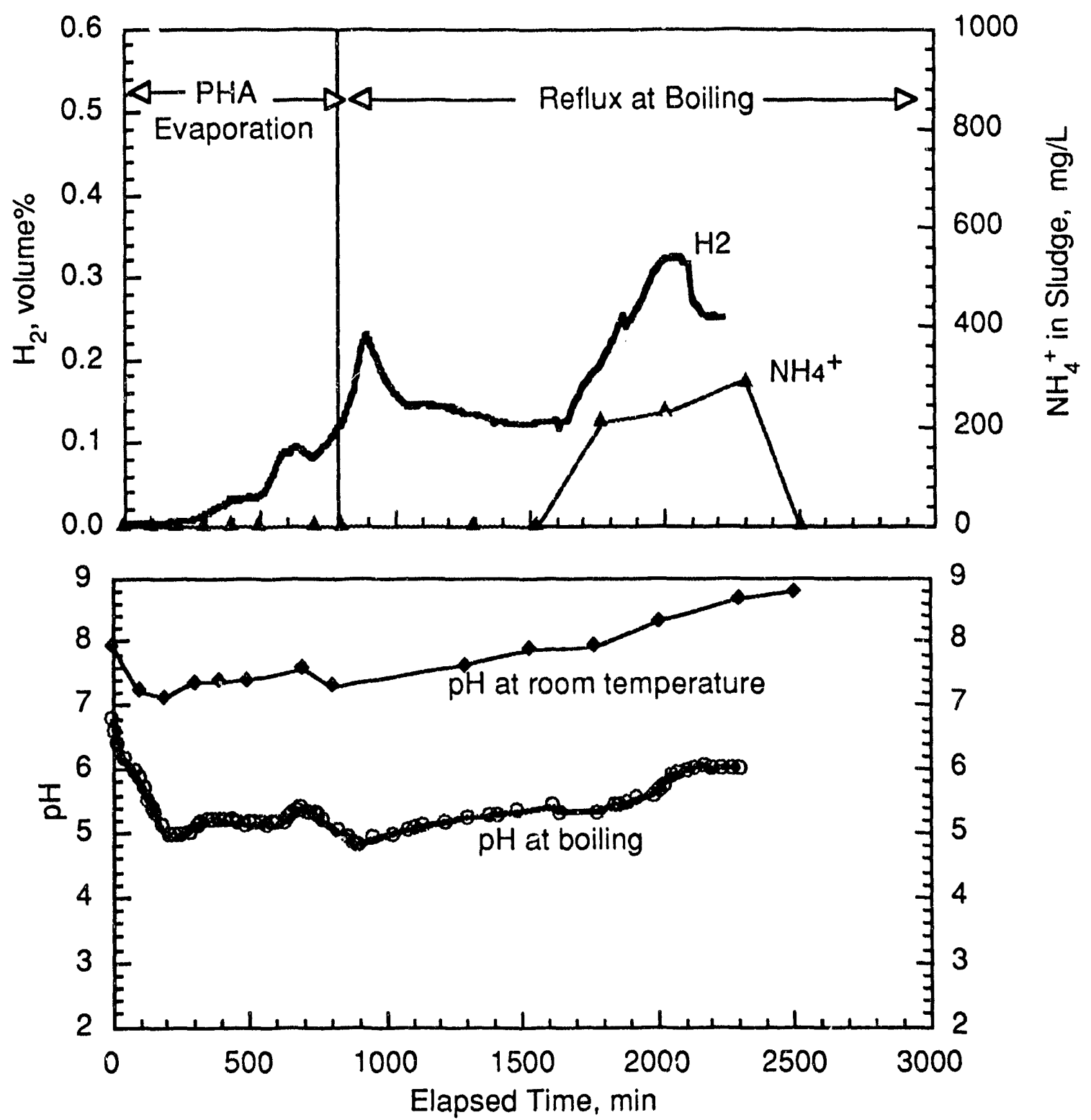

Figure 3. Ammonium, hydrogen and pH profiles of Run\#15 

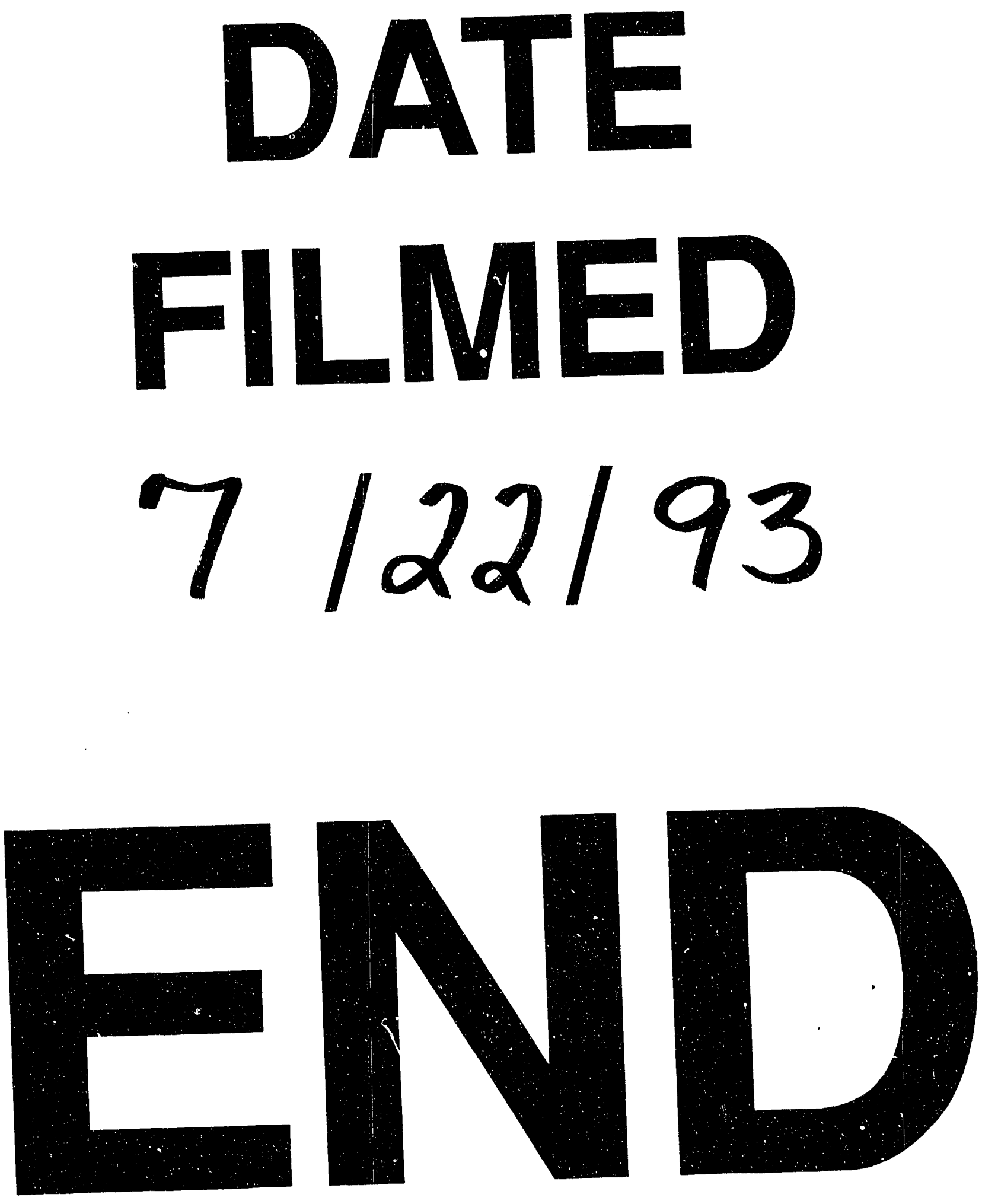
